\title{
Moral Distress Assessment in the Nursing Team of a Hematology-Oncology Sector
}

\author{
Avaliação do Sofrimento Moral na equipe de enfermagem de um setor de Hemato-Oncologia
}

Evaluación del Sufrimiento Moral en el equipo de enfermería de un sector de Hemato-Oncología

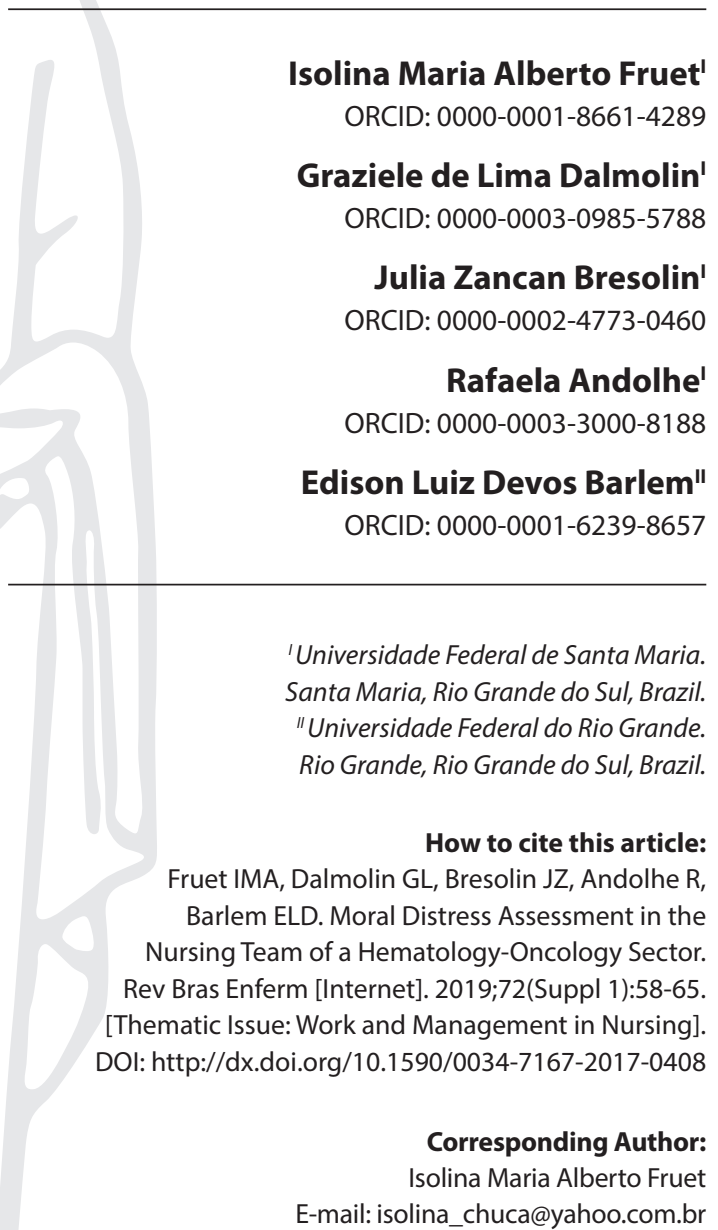

Submission: 06-11-2017
Approval:03-06-2018

\section{ABSTRACT}

Objective: To identify the frequency and intensity of Moral Distress, and to analyze the associations between Moral Distress and sociodemographic and labor characteristics of the nursing team of a Hematology-Oncology. Method: A cross-sectional study was carried out with 46 nursing professionals from a Hematology-Oncology sector of a hospital institution in Rio Grande do Sul State, Brazil, through the application of the Moral Distress Scale - Brazilian version. In the data analysis, descriptive statistics and nonparametric association tests were used. Results: Mortal Distress intensity of 3.27 $(S D=1.79)$ and frequency of $1.72(S D=1.02)$ were found in this team. The Moral Distress of greater intensity and frequency were related to the denial of the role of Nursing as a patient's advocate and the disrespect to the patient's autonomy, respectively. Conclusions: It is suggested a greater space for discussion among professionals, multiprofessional team and managers, so that adequate conditions of action and communication are provided.

Descriptors: Nursing; Ethics in Nursing; Occupational Health; Oncology; Psychological Stress.

\section{RESUMO}

Objetivo: Identificar a frequência e intensidade do Sofrimento Moral, e analisar as associações entre Sofrimento Moral e características sociodemográficas e laborais da equipe de enfermagem de um setor de Hemato-Oncologia. Método: Estudo transversal, realizado com 46 profissionais de enfermagem de um setor de HematoOncologia de uma instituição hospitalar do Rio Grande do Sul, por meio da aplicação da escala Moral Distress Scale - Versão brasileira. Empregou-se, na análise dos dados, estatística descritiva e testes de associação não paramétricos. Resultados: Verificouse média de intensidade do Sofrimento Moral de $3,27(D P=1,79)$ e frequência de $1,72(\mathrm{DP}=1,02)$ nessa equipe. O Sofrimento Moral de maior intensidade e frequência foram referentes à negação do papel da Enfermagem como advogada do paciente e o desrespeito à autonomia do paciente, respectivamente. Conclusões: Sugere-se maior espaço de discussão entre profissionais, equipe multiprofissional e chefias, para que sejam proporcionadas adequadas condições de atuação e comunicação.

Descritores: Enfermagem; Ética em Enfermagem; Saúde do Trabalhador; Oncologia; Estresse Psicológico.

\section{RESUMEN}

Objetivo: Identificar la frecuencia e intensidad del Sufrimiento Moral y analizar las asociaciones entre el Sufrimiento Moral y las características sociodemográficas y laborales del equipo de enfermería de un sector de Hemato-Oncología. Método: Estudio transversal, realizado con 46 profesionales de enfermería de un sector de HematoOncología de una institución hospitalaria de Rio Grande do Sul, por medio de la aplicación de la escala Moral Distress Scale - Versión brasileña. Se empleó, en el análisis de los datos, estadística descriptiva y pruebas de asociación no paramétricas. Resultados: Se verificó una media de intensidad del Sufrimiento Moral de $3,27(D P=1,79)$ y la frecuencia de $1,72(D P=1,02)$ en ese equipo. El Sufrimiento Moral de mayor intensidad y frecuencia fueron referentes a la negación del papel de la enfermería como abogada del paciente y el irrespeto a la autonomía del paciente, respectivamente. Conclusión: Se sugiere mayor espacio de discusión entre profesionales, equipo multiprofesional y jefaturas, para que sean proporcionadas adecuadas condiciones de actuación y comunicación.

Descriptores: Enfermería; Ética en Enfermería; Salud Laboral; Oncología; Estrés Psicológico. 


\section{INTRODUCTION}

Currently, cancer - characterized as a Nontransmissible Chronic Disease - is among the most frequent causes of death in the Brazilian context, constituting a complex public health problem in the Brazilian Health Network, mainly in view of its estimates and increasing number of cases, which give it an epidemiological and socio-economic magnitude. It is noteworthy, however, that at least one third of the incidence of new cancers in the world could be prevented. In 2012, an estimated 14.1 million new cancers and 8.2 million cancer deaths worldwide, according to data from the International Agency for Research on Cancer and the World Health Organization ${ }^{(1-2)}$.

In Brazil, it is estimated, for the biennium 2018-2019, that approximately 640,000 new cases of cancer/year will occur. It is also expected that 21.4 million new cancers by 2030 and 13.2 million cancer deaths during this period, due to the growth and aging of the population, as well as a reduction in infant mortality and deaths by infectious diseases in developing countries ${ }^{(1-2)}$.

When considering these epidemiological data, care for cancer patients and their relatives/caregivers needs to be understood as a singular moment that demands special attention, since this process is permeated by fear, doubts, insecurity, which demands an ethical and commitment of health professionals. In this context, the fragility and anguish of the patients and their relatives/caregivers in the face of the diagnosis, course of the disease and treatment are common, and it is fundamental to clarify doubts, curiosities and seek to meet expectations, to act in the preservation of their rights, as a way to alleviate the anxiety and worry of the moment ${ }^{(2-3)}$.

In this sense, the nursing team has a fundamental role as support to patients and their families / caregivers throughout the period of cancer treatment, since its characteristic of being full time in health institutions and services, remaining longer with the patient. Due to the particularities of the patients and oncological treatments, in a service said of high complexity, nursing care, in this specificity, exceeds the limit of the technical-scientific knowledge of competence of the profession ${ }^{(2)}$. It is fundamental, in this treatment, the commitment and development of sensitivity, because there are several difficult moments and frustration, since it is often necessary to live with situations in which the cure of the patient is no longer possible(2).

The nursing team, in particular of an oncology treatment service, presents itself as a connection between the patient/ family and the multiprofessional team. They seek to provide full patient care, and they also need to develop strategies that can alleviate their own wear and suffering, often frequent in their daily work routine(2-4).

Nursing professionals are then recognized as moral agents in this context, because they act with ethical and moral responsibility in the development of their activities and also in the defense of patients' rights, seeking to act in a manner consistent with their values and beliefs, reinforcing their integrity moral. In several situations, they need to act in the defense of care for patients/ caregivers, but this exercise of moral agency is often influenced by flexibility in the work environment ${ }^{(2,5)}$.

Thus, when faced with moral problems, nursing professionals constantly need to act in a way contrary to their personal and professional beliefs and values, which can lead them to experience Moral Distress (MD) ${ }^{(2)}$. MD is understood as a psychological imbalance experienced in situations in which the professional distinguishes the ethically appropriate action to be implemented, but is prevented from acting according to his conscience by institutional constraints, legal, political considerations, among others, feeling as inadequate his moral participation ${ }^{(6)}$. MD can also be characterized as an indicator of the moral engagement of professionals with professional practice, when one consents or makes confrontations with practices or environments that limit them in terms of ethical performance ${ }^{(7)}$.

In view of the aspects covered, the relevance of MD research in the field of Nursing in Hematology-Oncology $(\mathrm{HO})$ is highlighted, as its professionals daily experience moral problems that may involve differences in perception in the multiprofessional team about the care and treatment of patients oncologists and their families/caregivers, such as finding futile care for these patients, as well as facing difficulties in the institution's own work organization, which may limit the quality of the service provided, which implies a lack of personnel and material resources.

In a search conducted in the Latin American and Caribbean Literature on Health Sciences (LILACS), SciVerse Scopus (SCOPUS) and Cumulative Index to Nursing and Allied Health Literature (ClNAHL) databases in January 2016, "Moral Distress", "Nursing" and "Ethics", we selected 30 productions that addressed the theme of $\mathrm{MD}$ assessment, but of these, only two $\mathrm{HO}^{(8)}$, one in the North American context ${ }^{(9)}$ and another in the Italian context ${ }^{(10)}$. Thus, in the Brazilian context, there was a gap regarding the assessment of $\mathrm{MD}$ in the specific environment of Nursing in $\mathrm{HO}^{(2)}$. It is relevant to conduct this study to investigate the population in question, since this environment presents particularities that differentiate them from studies found in the international literature, such as public health policy, professional legislation, work organization, etc.

Thus, the present study presented as guiding questions: What is the assessment of Moral Distress in the $\mathrm{HO}$ nursing team? Are there associations between Moral Distress and the sociodemographic and labor characteristics of the HO nursing team?

\section{OBJECTIVE}

To identify the frequency and intensity of Moral Distress, and to analyze the associations between Moral Distress and sociodemographic and labor characteristics of the nursing team of the Hematology-Oncology Sector.

\section{METHOD}

\section{Ethical aspects}

Resolution 466/12 and its precepts regarding ethics in research involving human beings were respected. The present project obtained a favorable opinion from the Local Research Ethics Committee on 01/12/2015, through the Certificate of Presentation for Ethical Appreciation. For the data collection, the participants signed the Free and Informed Consent Term, which was delivered in two ways, with the research tool. The anonymity of the participants was preserved. 


\section{Design, place of study and period}

This is a cross-sectional research, resulting from a Master's dissertation research carried out at a Public Federal University Hospital, in a city of Rio Grande do Sul State, a reference in health ${ }^{(2)}$. This institution acts as a teaching hospital with the linkage of teaching, research and extension activities. The study was carried out in the $\mathrm{HO}$ sector, which includes the outpatient units of chemotherapy, radiotherapy, bone marrow transplantation center and Pediatric Oncology unit. In these units, there are 52 nursing professionals, that is: 26 nurses, 18 nursing technicians and 8 nursing assistants. The data collection took place from January to March 2015, by collectors previously trained by the researcher in charge. The professionals were invited to participate in the research and answer the questionnaire during the work shift. The mean filling time was 20 minutes. A schedule for the return of the tool completed with the signed Free and Informed Consent Term route was scheduled. Up to three attempts were made to search for tools.

\section{Population or sample}

The nonprobabilistic sample was used for convenience, adopting the criterion of availability of the participants in accepting to participate in the study during the period of data collection. However, to reduce possible biases in relation to the sample, a sample calculation was performed for finite population ${ }^{(11)}$, which estimates a minimum sample size. Thus, taking into account the population of 52 nursing professionals in the $\mathrm{HO}$ sector, a minimum sample of 45 participants was obtained when applying the formula. However, all nursing professionals in the $\mathrm{HO}$ sector were invited to participate in the research. The final sample consisted of 46 professionals from the nursing team ( 23 nurses, 18 nursing technicians and five nursing assistants).

\section{Criteria of inclusion and exclusion}

The inclusion criterion was the minimum 30-day performance in the sector and, as exclusion criteria, any leave of absence, such as leave or health leave in the period of data collection. Six professionals refused to participate in the study.

\section{Study protocol}

The study protocol comprised an initial part of sociodemographic and work characterization, and the Moral Distress Scale (MDS) - Brazilian Version, which was originally constructed in the North American context and later translated and adapted transculturalally to the Brazilian context ${ }^{(2,12-13)}$. The scale consists of 39 issue on a seven-point Likert scale, ranging from 0 to 6 , which assesses the intensity and frequency of $\mathrm{MD}^{(2,13)}$.

\section{Analysis of results and statistics}

In the data analysis, the PASW Statistic ${ }^{\circledR}$ (Predictive Analytics Software, SPSS Inc., Chicago, USA) version 18.0 for Windows was used. The analysis of the intensity and frequency of the MD was operationalized through each of the three factors of the tool and the analysis of the general MD, all three being considered. The factors "Lack of competence in the team", "Denial of the role of Nursing as a patient's advocate" and "Disrespect to the patient's autonomy" were identified during a factorial analysis of the tool in the verification of its applicability to the context of $\mathrm{HO}^{(13)}$.

Descriptive statistics were used, with the presentation of measures of central position, as averages by comparison with other studies that adopted the same tool, and medians by the asymmetric distribution of the data. The normality of the data was verified by the Kolmogorov-Smirnov test. The Mann Whitney and Kruskal Wallis $\mathrm{U}$ tests were used for the association of the MD factors with the characteristics of the participants, with a significance level of $95 \%(p<0.05)$.

\section{RESULTS}

The professionals of the nursing team in the research sector were mostly women (44-95.7\%), married (35-76.1\%) and with a child (1941.3\%). As for the professional category, 23 (50\%) were nurses, 18 (39.1\%) nursing technicians and five (10.9\%) nursing assistants. With regard to qualification, the majority had specialization (30-65.2\%), with only seven (15.21\%) in the Oncology area specifically. They presented median age of 36 years, professional training time of 21 years and time of operation in the institution of 7.2 years. Most were working in the $\mathrm{HO}$ service for less than five years (27-58.7\%). The majority worked on the night shift (17-37\%), followed by the morning shift (12-26.1\%).

From the descriptive analysis of the MD assessment scale, the perception of the nursing team regarding the MD was identified. Table 1 shows the descriptive values, including mean, standard deviation and median, for each of the issue that compose the factor "Lack of competence in the work".

Table 2 shows the descriptive measures of the factor "Denial of the role of Nursing as a patient's advocate".

Table 3 shows the descriptive measures of the factor "Disrespect to the patient's autonomy".

Finally, the general descriptive measures of the three factors, as well as the overall MD, are presented, joining all the measures (Table 4).

It is observed that the factor of greater intensity of MD for the nursing team of the $\mathrm{HO}$ was the "Denial of the role of Nursing as a patient's advocate", with the question "i34: Avoiding taking action in situations of death of patients associated with professional negligence" with the highest average of 3.85 (SD: 2.28).

Regarding the frequency of MD, the "Disrespect to the patient's autonomy" factor was highlighted, with the question "i02: Following the family's will to maintain the patient's life, although this is not the best for him/her" of frequency, (2.96) (SD: 1.92).

Finally, associations between the MD factors and the sociodemographic and labor characteristics of the $\mathrm{HO}$ nursing team were identified (Table 5).

In relation to the tested associations of the perception of $\mathrm{MD}$ with the sociodemographic and labor characteristics of the nursing team, some items with a statistically significant difference were identified at the $5 \%$ level. The variables with the difference were: working time in the sector, professional category, schooling, presence of dialogue in the team, ethics committee and permanent education in the institution. 
Table 1 - Descriptive analysis of the issues that compose the factor "Lack of competence in the team", Rio Grande do Sul State, Brazil, 2017

\begin{tabular}{|c|c|c|c|c|c|c|}
\hline \multirow{2}{*}{$\begin{array}{l}\text { Lack of competence in the team } \\
\text { Issues }\end{array}$} & \multicolumn{3}{|c|}{ Intensity } & \multicolumn{3}{|c|}{ Frequency } \\
\hline & Mean & SD & Me & Mean & SD & Me \\
\hline i24- Working with nurses who do not have the necessary competence that the patient's condition requires. & 3.07 & 2.05 & 3.00 & 1.41 & 1.42 & 1.00 \\
\hline $\begin{array}{l}\text { i25- Working with nursing technicians/assistants who do not have the necessary competence that the patient's } \\
\text { condition requires. }\end{array}$ & 3.11 & 2.10 & 3.50 & 1.67 & 1.49 & 1.00 \\
\hline $\begin{array}{l}\text { i26- Working with medical or nursing students who do not have the necessary competence that the patient's } \\
\text { condition requires. }\end{array}$ & 3.22 & 2.04 & 4.00 & 1.96 & 1.53 & 2.00 \\
\hline i27- Working with doctors who do not have the required competence that the patient's condition requires. & 3.70 & 2.11 & 4.5 & 2.37 & 1.78 & 2.00 \\
\hline i28-Working with support services that do not have the necessary competence that the patient's condition requires. & 3.37 & 1.99 & 4.00 & 2.17 & 1.65 & 2.00 \\
\hline i29- Working with nurses who do not have the competence to act. & 3.22 & 2.18 & 4.00 & 1.37 & 1.24 & 1.00 \\
\hline i30-Work with technicians/assistants who do not have the competence to act. & 3.11 & 2.14 & 3.50 & 1.41 & 1.34 & 1.00 \\
\hline i31- Working with doctors who do not have the competence to act. & 3.48 & 2.27 & 4.0 & 1.87 & 1.63 & 1.00 \\
\hline i32-Working with support services that do not have the competence to act. & 3.33 & 2.03 & 4.00 & 1.83 & 1.64 & 1.00 \\
\hline i33-Working with medical or nursing students who do not have the competence to act. & 3.37 & 1.99 & 4.00 & 1.96 & 1.58 & 2.00 \\
\hline
\end{tabular}

Table 2 - Descriptive analysis of the factor "Denial of the role of Nursing as a patient's advocate", Rio Grande do Sul State, Brazil, 2017

\begin{tabular}{|c|c|c|c|c|c|c|}
\hline \multirow{2}{*}{$\begin{array}{l}\text { Denial of the role of Nursing as a patient's advocate } \\
\text { Issues }\end{array}$} & \multicolumn{3}{|c|}{ Intensity } & \multicolumn{3}{|c|}{ Frequency } \\
\hline & Mean & SD & Me & Mean & SD & Me \\
\hline i07- Ignoring situations where the patient has not been given the appropriate information to ensure informed consent. & 3.35 & 2.06 & 4.00 & 2.17 & 1.58 & 2.00 \\
\hline $\begin{array}{l}\text { i09- Avoiding taking action when finding that a member of the nursing team applies the wrong medication and fails to } \\
\text { report it. }\end{array}$ & 3.44 & 2.46 & 5.00 & 1.28 & 1.38 & 1.00 \\
\hline i10- Allowing medical students to perform painful procedures on patients just to hone their skills. & 3.57 & 2.37 & 5.00 & 1.43 & 1.77 & 1.00 \\
\hline $\begin{array}{l}\text { i11- Assisting doctors who are performing procedures on patients after cardiorespiratory recovery has not been } \\
\text { satisfactory. }\end{array}$ & 3.02 & 2.32 & 3.00 & 1.04 & 1.37 & 1.0 \\
\hline i12- Performing medical prescriptions for unnecessary exams and treatments in terminally ill patients. & 3.02 & 2.25 & 3.00 & 1.67 & 1.92 & 1.00 \\
\hline i13- Working with nursing staff at a level that they consider "unsafe". & 3.24 & 2.13 & 4.00 & 1.62 & 1.51 & 1.00 \\
\hline i16- Observing, without taking action, when the nursing team does not respect the patient's privacy. & 2.98 & 2.20 & 3.00 & 1.50 & 1.43 & 1.00 \\
\hline i17- Obeying the medical request not to tell the truth to the patient, even when the patient asks the truth. & 3.17 & 2.16 & 4.00 & 1.24 & 1.45 & 1.00 \\
\hline i18- Assisting a doctor who, in his opinion, is acting incompetently with the patient. & 3.35 & 2.45 & 4.00 & 1.59 & 1.60 & 1.00 \\
\hline i34- Avoiding taking action in situations of death of patients associated with professional negligence. & 3.85 & 2.28 & 5.00 & 1.78 & 1.67 & 1.00 \\
\hline i38- Avoiding taking action when you notice the terminal patient's abandonment by the health team. & 3.58 & 2.16 & 5.00 & 1.50 & 1.39 & 1.00 \\
\hline i39- Avoiding taking action when realizing the termination of the terminal patient by the family. & 3.69 & 2.29 & 5.00 & 1.78 & 1.83 & 1.00 \\
\hline
\end{tabular}

Table 3 - Descriptive analysis of the factor "Disrespect to the patient's autonomy", Rio Grande do Sul, Brazil, 2017

\begin{tabular}{|c|c|c|c|c|c|c|}
\hline \multirow{2}{*}{$\begin{array}{l}\text { Disrespect to the patient's autonomy } \\
\text { Issues }\end{array}$} & \multicolumn{3}{|c|}{ Intensity } & \multicolumn{3}{|c|}{ Frequency } \\
\hline & Mean & SD & Me & Mean & SD & Me \\
\hline i02- Following the family's will to maintain the patient's life, although this is not the best for him/her. & 3.28 & 1.91 & 4.00 & 2.96 & 1.92 & 3.00 \\
\hline i21- Accomplishing the doctor's request not to discuss with the patient his or her resuscitation in case of cardiac arrest. & 2.63 & 2.10 & 3.00 & 1.63 & 1.68 & 1.00 \\
\hline $\begin{array}{l}\text { i22- Accomplishing the doctor's request not to discuss with the family resuscitation of the patient in case of } \\
\text { cardiac arrest, when the patient is devoid of discernment. }\end{array}$ & 2.83 & 2.11 & 3.00 & 1.50 & 1.62 & 1.00 \\
\hline i36- Acting with professionals who do not clarify the patient about his state of health and illness. & 3.00 & 1.89 & 3.00 & 2.00 & 1.59 & 2.00 \\
\hline
\end{tabular}

Table 4 - Descriptive analysis of the intensity and frequency of Moral Distress experienced by the nursing team of the Hematology-Oncology sector according to factors of the Moral Distress Scale - Brazilian Version, Rio Grande do Sul State, Brazil, 2017

\begin{tabular}{|c|c|c|c|c|c|c|}
\hline \multirow{2}{*}{ Variables } & \multicolumn{3}{|c|}{ Intensity } & \multicolumn{3}{|c|}{ Frequency } \\
\hline & Mean & SD & Me & Mean & SD & Me \\
\hline Lack of competence in the team & 3.30 & 1.95 & 3.75 & 1.80 & 1.28 & 1.45 \\
\hline Denial of the role of Nursing as a patient's advocate & 3.37 & 1.95 & 4.25 & 1.57 & 1.10 & 1.36 \\
\hline Disrespect to the patient's autonomy & 2.93 & 1.91 & 4.00 & 2.02 & 1.30 & 1.88 \\
\hline General Moral Distress & 3.27 & 1.79 & 3.71 & 1.72 & 1.02 & 1.62 \\
\hline
\end{tabular}


Table 5 - Relation between the perceptions of Moral Distress of the nursing professionals of the Hematology-Oncology service, according to identified factors, and sociodemographic and labor variables, Brazil, 2017

\begin{tabular}{|c|c|c|c|c|c|c|c|c|c|}
\hline \multirow[t]{2}{*}{ Variables } & \multicolumn{3}{|c|}{$\begin{array}{l}\text { Lack of competence } \\
\text { in the team }\end{array}$} & \multicolumn{3}{|c|}{$\begin{array}{l}\text { Denial of the role of Nursing } \\
\text { as a patient's advocate }\end{array}$} & \multicolumn{3}{|c|}{$\begin{array}{l}\text { Disrespect to the } \\
\text { patient's autonomy }\end{array}$} \\
\hline & $\mathbf{n}$ & $\mathbf{M}$ & $\mathbf{P}$ & n & M & $\mathbf{P}$ & $\mathbf{n}$ & $\mathbf{M}$ & $\mathbf{P}$ \\
\hline \multicolumn{10}{|l|}{ Professional Category } \\
\hline Nurse & 23 & 26.9 & 0.08 & 23 & 25.6 & 0.27 & 23 & 28.1 & $0.05^{*}$ \\
\hline Nursing technician & 18 & 22.1 & & 18 & 23.2 & & 18 & 20 & \\
\hline Nursing assistant & 05 & 12.8 & & 05 & 15 & & 5 & 14.9 & \\
\hline \multicolumn{10}{|l|}{ Schooling } \\
\hline High School & 1 & 16 & 0.13 & 1 & 10.5 & 0.16 & 1 & 15.5 & $0.04 *$ \\
\hline Undergraduate Degree & 7 & 13 & & 7 & 15.3 & & 7 & 11 & \\
\hline Specialization & 30 & 25.7 & & 30 & 26.4 & & 30 & 25.6 & \\
\hline Master's Degree & 8 & 25.4 & & 8 & 21.5 & & 8 & 27.5 & \\
\hline \multicolumn{10}{|l|}{ Work Time } \\
\hline$\leq 21$ years & 23 & 24.9 & 0.46 & 23 & 24.6 & 0.47 & 23 & 24.8 & 0.51 \\
\hline$>21$ years & 23 & 22.1 & & 23 & 22.4 & & 23 & 22.2 & \\
\hline \multicolumn{10}{|l|}{ Institution Time } \\
\hline$\leq 5$ years & 18 & 19.9 & 0.14 & 18 & 19.2 & 0.07 & 18 & 21.9 & 0.52 \\
\hline$>5$ years & 28 & 25.8 & & 28 & 26.3 & & 28 & 24.5 & \\
\hline \multicolumn{10}{|l|}{ Sector } \\
\hline 1. CTCRIAC & 23 & 21.3 & 0.51 & 23 & 21.6 & 0.51 & 23 & 28.2 & 0.54 \\
\hline 2. СTMO & 11 & 28.6 & & 11 & 28.7 & & 11 & 28.2 & \\
\hline 3. Chemotherapy Ambulatory & 7 & 24.1 & & 7 & 23.6 & & 7 & 23.2 & \\
\hline 4. Radiotherapy & 5 & 21.9 & & 5 & 20.9 & & 5 & 24.6 & \\
\hline \multicolumn{10}{|l|}{ Sector Time } \\
\hline$\leq 5$ years & 27 & 20.7 & 0.09 & 27 & 20.1 & $0.03^{*}$ & 27 & 21.0 & 0.13 \\
\hline$>5$ years & 19 & 27.5 & & 19 & 28.4 & & 19 & 27 & \\
\hline \multicolumn{10}{|l|}{ Work shift } \\
\hline Morning & 29 & 21.2 & 0.12 & 29 & 19.7 & 0.12 & 29 & 22.6 & 0.53 \\
\hline Evening & 17 & 27.5 & & 17 & 30.0 & & 17 & 28.1 & \\
\hline \multicolumn{10}{|l|}{ Dialogue with the Institution } \\
\hline Yes & 21 & 21.6 & 0.63 & 21 & 21.1 & 0.61 & 21 & 21.7 & 0.78 \\
\hline No & 2 & 18.5 & & 2 & 21.8 & & 2 & 21.3 & \\
\hline Sometimes & 22 & 24.8 & & 22 & 25 & & 22 & 24.4 & \\
\hline \multicolumn{10}{|l|}{ Dialogue with the Chief } \\
\hline Yes & 27 & 21.7 & 0.66 & 27 & 21.8 & 0.65 & 27 & 21.3 & 0.23 \\
\hline No & 2 & 21.5 & & 2 & 29.5 & & 2 & 37.3 & \\
\hline Sometimes & 16 & 25.4 & & 16 & 24.2 & & 16 & 24.1 & \\
\hline \multicolumn{10}{|l|}{ Dialogue with the Team } \\
\hline Yes & 36 & 21.4 & 0.10 & 36 & 21.6 & 0.15 & 36 & 21.0 & $0.03^{*}$ \\
\hline Sometimes & 9 & 29.4 & & 9 & 28.6 & & 9 & 31.2 & \\
\hline \multicolumn{10}{|l|}{ Meetings } \\
\hline Monthly & 1 & 34.0 & 0.18 & 1 & 31.0 & 0.29 & 1 & 35.0 & 0.15 \\
\hline When needed & 37 & 19.1 & & 37 & 19.2 & & 37 & 19.1 & \\
\hline \multicolumn{10}{|l|}{ Knowledge on Ethics Comission } \\
\hline Yes & 22 & 27.6 & $0.02 *$ & 22 & 27.3 & $0.02 *$ & 22 & 25.3 & 0.30 \\
\hline No & 4 & 12.9 & & 4 & 11.8 & & 4 & 15.6 & \\
\hline I don't know & 18 & 18.5 & & 18 & 19 & & 18 & 20.4 & \\
\hline \multicolumn{10}{|l|}{ Permanent Education } \\
\hline Yes & 34 & 25.1 & $0.04^{*}$ & 34 & 25.6 & $0.02^{*}$ & 34 & 24.9 & $0.02 *$ \\
\hline No & 3 & 6.0 & & 3 & 5.5 & & 3 & 3.5 & \\
\hline I don't know & 8 & 20.5 & & 8 & 18.3 & & 8 & 22.4 & \\
\hline
\end{tabular}

Regarding the working time in the sector, it was identified that the professionals with more than five years of work had greater MD related to the factor denying the role of Nursing as a patient's advocate. Regarding the professional category, educational level and the possibility of dialogue in the team, it was identified that nurses who had postgraduate degrees and those who reported 
that there was a presence of dialogue in the team, presented higher MD related to disrespect the patient's autonomy.

Finally, those who responded positively to the knowledge about the ethics committee in the institution presented higher MD in the factors Lack of competence in the nursing team and Denial of the role of Nursing as a patient's advocate. Similarly, professionals who reported that there were permanent education actions at the institution had a higher MD in all three factors.

\section{DISCUSSION}

From the analysis of the results, it was identified that the factor of greater intensity of MD, in the present study, refers to the denial of the role of Nursing as a patient's advocate. This result was different from that found with nursing professionals from Oncology units in pediatric hospitals in Italy, in which the highest MD factor identified was work with doctors who did not have the competence to act $^{(10)}$.

The role of the patient's advocate is not something exclusive to Nursing, as it is also practiced by different health professionals. However, due to the greater proximity of the nursing team to the patient, they increase their possibilities of practicing advocacy, which may lead to the strengthening of Nursing as a profession ${ }^{(14)}$. Some nursing professionals exercise their roles as patient advocates and are successful. This experience can positively affect future Nursing practice. However, others try to intervene for their patients and are not heard, which can be negative, since many professionals stated that they would not take action in similar situations in the future, since the advocacy role was not satisfactory ${ }^{(15)}$.

The most frequent occurrence factor was disrespect to the patient's autonomy. In Jordan, a similar factor, known as "acquiescence to patient rights violations", was identified as having the lowest intensity and frequency in mental health nurses, among other factors, such as unethical behavior by caregivers and insufficient human resources ${ }^{(16)}$.

Regarding the MD associations with sociodemographic and labor variables, the following items presented a statistically significant difference.

The longer time of five years in the sector was associated with a higher perception of MD. In Oncology units in Iran, the time of experience in the area was also positively correlated to the MD. The greatest MD in professionals with longer working hours may be associated with moral residue, which describes the feelings that persist even with the past problematic situation. The moral residue is cumulative, because in each dilemma or conflict situation, the remaining feelings are aroused and, consequently, they increase, and can compromise the moral integrity of the professional, making each MD situation more distressing ${ }^{(17)}$.

In terms of the professional category and schooling, higher education nurses had a higher incidence of MD, which may be related to differences in professional training when compared to courses in the other categories of Nursing. Nurses have their training based heavily on the scientific aspect of Nursing as a science, based on ethical, social and political principles, which respect the human being in its entirety ${ }^{(2)}$. In this sense, it becomes a moral agent in its work with the patient, especially in situations involving differences in autonomy, judgments, conflicts, defense and sensitivity ${ }^{(18-19)}$, since they encourage greater criticality, reflection and issues about professional doing ${ }^{(2)}$.

The possibility of dialogue in the working environment associated to the MD was also assessed. As most of the participants indicated that it is not a constant, sometimes it can be said that this fact may be associated with the MD in regard to disrespect to the patient's autonomy. From this perspective, it is important to valorize and encourage the construction of spaces for discussion or problematization of issues related to patient care and simple communication of information, both informally and in rounds of the multiprofessional team ${ }^{(2,20)}$.

It was observed that professionals who reported knowing that the institution had an ethics committee, and probably participated in them, had a higher MD related to disrespect to the patient's autonomy and lack of competence in the team. In the same way, with the Permanent Education, the participants who knew this institutional policy and its actions and probably also of them participated, demonstrated greater MD in the three factors.

It has been found that the ethics committee is one of the resources most used to deal with distressing circumstances with intensive care nurses and temporary care. Since, according to the participants, recognition of the situation and the collaborative, interprofessional and respectful climate is what creates an environment to address morally distressing situations ${ }^{(21)}$.

It should be noted that many professionals, in the course of their activities, face various conflicts, dilemmas and ethical problems related to the work environment and the institution. As a result, professionals face inconsistencies between their personal and professional values that they cannot manage, and as a result, they choose to leave the profession because they lack support in coping with these situations ${ }^{(10)}$.

To avoid the occurrence of MD, some strategies, such as the so-called "four As", developed by the American Association of Critical-Care Nurses, can be adopted. In this strategy the "four As" refer to: 1) Ask- that deals with the questioning of the daily situations that distress the professional or the manifestations of signs of the MD; 2) Affirm - which refers to the act of proving suffering and taking responsibility for your own care. This strategy can be used with others to assist in proving the suffering experienced; 3) Assessing the identification of the sources that are causing the suffering with assessment of actions to change them, indicates the joint construction of the heads of an action project to implement it; and, lastly, 4) Act - which refers to the implementation and use of strategies to effect change and preserve the moral integrity of professionals ${ }^{(22)}$.

In addition to these strategies, other recommendations are suggested in order to avoid the ethical impact of MD, such as the application of a participatory approach in establishing rules, promoting autonomy, recognizing the role of Nursing as a patient advocate, improving physical and the expansion of the health budget $^{(23)}$. In addition, policy development, with institutional support, focused on inclusive communication and interprofessional education, can work to effectively change organizational cultures, promote recognition and respect for the role of the nursing professional as a member of the multiprofessional team ${ }^{(24)}$.

Finally, in a hospital in the Southwest of the United States, the medical and surgical nurses who presented the highest 
scores for the MD intensity were those who cared for Oncology and transplant patients ${ }^{(25)}$. Thus, it is observed the need to offer discussion spaces about daily experiences and decision-making, as well as the search for strategies that reduce the occurrence of MD in the teams of nursing and health professionals, conflicts and dilemmas and ethical problems experienced in the daily coexistence with aggressive and long treatments, uncertainty of cure, futile care, palliative care, as well as the termination process.

\section{Study limitations}

The limitations of the study were the fact that the data collection was carried out during the summer, when several professionals were on vacation and also at a time of new hiring of nursing personnel from the implantation of the Brazilian Company of Hospital Services (EBSERH-Empresa Brasileira de Serviços Hospitalares) at the research institution. Although the minimum criterion of 30 days in the sector was adopted, it is considered that many may not yet have experienced issues that could serve as a reference for MD assessment. However, even with its limitations, this study served as an overview of the MD with these Nursing professionals in a service of $\mathrm{HO}$ that presents a daily of conflicts and dilemmas related to the care of this public.

\section{Contributions to the Nursing}

The present study contributed as a reflection on the MD to the professionals of the nursing team working in the sector, providing a greater dialogue among colleagues regarding dilemmas and conflicts in the work environment. Consequently, it has contributed to the discussion of ethical issues around employee satisfaction and health, which reflects in improved patient care. Considering these aspects, it is suggested to routinely implement greater spaces of discussion among the nursing, multiprofessional and leadership teams, favoring more adequate conditions of professional practice and communication. In addition, the importance of the development of new studies in this population is highlighted, so that MD coping strategies are identified and implemented, in search of an ethically healthier work environment, in which professionals can, with greater autonomy, act in accordance with ethical and moral principles, preserving their moral integrity at work.

\section{CONCLUSION}

The study investigated the intensity and frequency of MD in the nursing team of a $\mathrm{HO}$ sector. There was an intensity of 3.27 and a frequency of 1.72. Regarding the MD factors, the highest intensity was "Denial of the role of Nursing as a patient's advocate", and the most frequent, "Disrespect to the patient's autonomy", demonstrating, together with the issue that presented the highest averages in these factors, the difficulty of action and confrontation of the nursing team in the face of ethical problems that involve the defense of the rights of patients with cancer, coherently with what they consider the best for them.

With the analysis of the associations that obtained statistically significant results, it was observed that the professionals with more time of experience and that they had graduate (specialization or master's degree) had more occurrence of MD. This finding may be related to the greater possibilities, on the part of the professionals before their formation and experience, of reflection and problematization of the practice.

The knowledge about the presence of an ethics committee and the Permanent Education in the institution were also associated with a greater perception of $\mathrm{MD}$, which may represent a greater possibility of perception and discussion about the problematic situations and ethical and moral dilemmas present in the work environment.

Thus, it is considered the strengthening and instrumentalization of these professionals for an ethical action in the face of conflicts based on scientific knowledge and according to professional and personal values through the possibility of discussions and spaces of reflection with the multiprofessional team in the work environment, favoring the ethical organizational climate and the better management of the situations generating MD.

\section{REFERENCES}

1. Ministério da Saúde (BR), Instituto Nacional de Cancer José Alencar Gomes da Silva (INCA). Estimativa 2018: incidência de cancer no Brasil [Internet]. Rio de Janeiro: INCA; 2017 [cited 2018 Sep 05]. 128 p. Available from: http://www.inca.gov.br/estimativa/2018/estimativa-2018.pdf

2. Fruet IMA. Sofrimento moral em trabalhadores de enfermagem do serviço de hemato-oncologia [Dissertation on the Internet]. Santa Maria: Universidade Federal de Santa Maria; 2016 [cited 2018 Sep 5]. 70 p. Available from: https://repositorio.ufsm.br/bitstream/handle/1/7475/ FRUET\%2c\%20ISOLINA\%20MARIA\%20ALBERTO.pdf?sequence=1\&isAllowed=y

3. Vicenzi A, Scwartz E, Cecagno D, Viegas AC, Santos BP, Lima JF. [Comprehensive nursing care to the cancer patient and the Family]. Rev Enferm UFSM [Internet]. 2013 [cited 2017 Mar 15];3(3):409-417. Available from: https://periodicos.ufsm.br/reufsm/article/view/8816/pdf

4. Umann J, Silva RM, Benetti ERRB, Guido LA. Estresse e coping entre enfermeiros de unidade hemato-oncológica. Rev Rene [Internet]. 2013 [cited 2017 Mar 15];14(4):783-790. Available from: http://www.periodicos.ufc.br/index.php/rene/article/view/3545/2785

5. Robinson EM, Lee SM, Zollfrank A, Jurchak M, Frost D, Grace P. Enhancing moral agency: clinical ethics residency for nurses. Hastings Cent Rep [Internet]. 2014 [cited 2017 Mar 15];44(5):12-20. Available from: http://onlinelibrary.wiley.com/doi/10.1002/hast.353/epdf

6. Jameton A. Nursing practice: the ethical issues. Englewood Cliffs (NJ): Prentice-Hall. 1984. 331 p.

7. Carnevale FA. Confronting moral distress in nursing: recognizing nurses as moral agents. Rev Bras Enferm [Internet]. 2013 [cited 2017 Mar 15];66(spe):33-8. Available from: http://dx.doi.org/10.1590/S0034-71672013000700004

8. Fruet IMA, Dalmolin GL, Speroni KS. [Moral distress assessment instruments to Nursing workers: integrative review]. Rev Enferm UFSM 
[Internet]. 2017 [cited 2018 Mar 15]; 7(2):314-26. Available from: https://periodicos.ufsm.br/reufsm/article/viewFile/20716/pdf Portuguese.

9. Sirilla J. Moral distress in nurses providing direct care on impatient oncology units. Clin J Oncol Nurs. 2014;18(5):536-41. doi: 10.1188/14. CJON.536-541.

10. Lazzarin M, Biondi A, Dimauro S. Moral distress in nurses in oncology and haematology. Nurs. Ethics [Internet]. 2012 [cited 2017 Mar 15];19(2):183-195. Available from: http://journals.sagepub.com/doi/pdf/10.1177/0969733011416840

11. Hill MM, Hill A. Investigação por questionário. Lisboa: Sílabo; 2002. 377 p.

12. Barlem ELD, Lunardi VL, Lunardi GL, Tomaschewski-Barlem JG, Almeida AS, Hirsch CD. Psycometric characteristics of the moral distress scale in brazilian nursing professionals. Texto Contexto-Enferm [Internet]. 2014 [cited 2018 Jan 15];23(3):563-72. Available from: http://dx.doi. org/10.1590/0104-07072014000060013. English, Portuguese.

13. Fruet IMA, Dalmolin GL, Barlem ELD, Silva RM, Andolhe R Applicability of the Moral Distress Scale in the context of nursing in hematooncology services. Rev Gaúcha Enferm [Internet]. 2017 [cited 2018 Jan 15];38(4):e63060. Available from: http://seer.ufrgs.br/index.php/ RevistaGauchadeEnfermagem/article/view/63060/44963. English, Portuguese.

14. Barlem ELD, Lunardi VL, Lunardi GL, Tomaschewski JG, Silveira RS. Moral distress in everyday nursing: hidden traces of power and resistance. Rev Lat Am Enfermagem [Internet]. 2013 [cited 2017 Mar 15];21(1):293-399. Available from: http://dx.doi.org/10.1590/S010411692013000100002. English, Portuguese.

15. Wiegand DL, Funk M. Consequences of clinical situation that cause critical care nurses to experience moral distress. Nurs Ethics [Internet]. 2012 [cited 2017 Mar 15];19(4):479-487. Available from: http://journals.sagepub.com/doi/pdf/10.1177/0969733011429342

16. Hamaideh SH. Moral distress and its correlates among mental health nurses in Jordan. Int J Ment Health Nurs [Internet]. 2014 [cited 2017 Mar 15];23(1):33-41. Available from: http://onlinelibrary.wiley.com/doi/10.1111/inm.12000/epdf

17. Ameri M, Safavibayatneed Z, Kavousi A. Moral distress of oncology nurses and morally distressing situations in oncology units. Aust J Adv Nurs [Internet]. 2016 [cited 2017 Mar 15];33(3):6-12. Available from: http://www.ajan.com.au/Vol33/lssue3/1Ameri.pdf

18. Lunardi VL, Barlem ELD, Bulhosa MS, Santos SSC, Lunardi-Filho WD, Silveira RS, Bao ACP, Dalmolin GL. [Moral distress and the ethical dimension in nursing work]. Rev Bras Enferm [Internet]. 2009 [cited 2017 Mar 15];62(4):599-603. Available from: http://dx.doi.org/10.1590/ S0034-71672009000400018. Portuguese.

19. Canever BP, Prado ML, Backes VMS, Gomes DC. [Production of knowledge about the tranining of nurses in Latin America]. Gaúcha Enferm [Internet]. 2012 [cited 2017 Mar 15];33(4):211-220. Available from: http://dx.doi.org/10.1590/S1983-14472012000400026. Portuguese.

20. Dalmolin GL, Lunardi LV, Barlem ELD, Silva RS. Implications of moral distress on nurses and its similirities with burnout. Texto Contexto-Enferm [Internet]. 2012 [cited 2017 Mar 15];21(1):200-8. Available from: http://dx.doi.org/10.1590/S0104-07072012000100023. English, Portuguese

21. Wilson MA, Goettemoelller DM, Bevan Na, McCord JM. Moral distress: levels, coping and preferred interventions in critical care and transitional care nurses. J Clin Nurs [Internet]. 2013 [cited 2017 Mar 15];22(9-10):137-144. Available from: http://onlinelibrary.wiley.com/ doi/10.1111/jocn.12128/epdf

22. McCue C. Using the AACN framework to alleviate moral distress. Online J Issues Nurs. 2010;16(1):9. doi: 10.3912/OJIN.Vol16No01PPT02.

23. Atabay G, Çangarli BC, Penbek S. Impact of ethical climate on moral distress revisited multidimensional view. Nurs Ethics [Internet]. 2014 [cited 2017 Mar 15];22(1):103-16. Available from: http://journals.sagepub.com/doi/pdf/10.1177/0969733014542674

24. Reed PG, Rishel CJ. Epistemic injustice and nurse moral distress perspective for policy development. Int. J. Ment Health Nurs [Internet]. 2015 [cited 2017 Mar 15];28(3):241-244. Available from: http://journals.sagepub.com/doi/pdf/10.1177/0894318415585634

25. Rice EM, Rady MY, Hamrick A, Verheiide JL, Pendergast DK. Determinants of moral distress in medical and surgical nurses at an adult acute tertiary care hospital. J Nurs Manag [Internet]. 2008 [cited 2017 Mar 15];16(3):360-373. Available from: http://onlinelibrary.wiley.com/ doi/10.1111/j.1365-2834.2007.00798.x/epdf 